\title{
Method for substantiating the spheres of application of shunting locomotives at sorting stations
}

\author{
Nazirjon Aripov*, Shinpolat Suyunbaev, Farrukh Azizov, and Alfiya Bashirova \\ Tashkent State Transport University, Tashkent, Uzbekistan
}

\begin{abstract}
Shunting work on sorting wagons is carried out on steeper profiles and requires the operation of shunting diesel locomotives of a higher power. Many sorting operations use double traction of shunting locomotives in conditions of the highly outdated fleet of shunting diesel locomotives. However, the technology of operating two shunting locomotives requires substantiation of its scope of application. In this article, using the example of station "X", the technology of disbanding trains from the sorting hump is investigated in two ways: the first is the existing technology (work on disbanding trains is carried out using two shunting locomotives of the TEM-2 series), shunting locomotive of TEM-7 series. It has been determined that in the existing technology, the required processing capacity of the hill approaches its maximum value. When using the TEM-7 diesel locomotive, the maximum processing capacity of the hill increases by $27 \%$. The sphere of efficiency of the TEM-7 series locomotive instead of two TEM-2 was substantiated by the method of technical and economic calculations.
\end{abstract}

\section{Introduction}

The main function of sorting stations is to sort the wagons according to the directions of travel. The faster the wagons are sorted, the faster the station's performance and the railway as a whole will improve. Currently, there are several studies to accelerate the process of processing wagons at sorting stations using railway automation devices [1-4, etc.]. In particular, most of the research aims to improve the performance of a shunting locomotive at sorting stations [5-9, etc.]. However, in these studies, the scope of applying this or that shunting locomotive is not sufficiently substantiated based on technical and economic indicators. Therefore, it is necessary to substantiate the scope of applying shunting diesel locomotives on the sorting hump, taking into account capital investments.

As you know, the sorting hump has a large profile and, therefore, a shunting locomotive of a higher power is required to sort the wagons. At present, at station "X", due to the outdated fleet of shunting diesel locomotives, the disbandment of trains through the sorting hump is carried out simultaneously by two shunting locomotives the f TEM- 2 brand. The introduction of a more powerful locomotive will allow replacing two TEM-2 locomotives,

*Correponding author: shinbolat_84@mail.ru 
thereby reducing the required fleet by one unit. It is proposed to carry out sorting work at the station with a TEM-7 locomotive instead of two TEM-2. To do this, it is necessary, first of all, to compare the maximum processing capacity of station " $\mathrm{X}$ " with the required one, and then to determine the capital costs for the purchase and implementation of a more powerful locomotive. Calculations of existing technology were made according to option I, and the proposed one - according to option II.

\section{Materials and methods}

\subsection{Determination of recycling capacity of sorting hump}

The maximum processing capacity of the sorting hump depends on the technological cycle of time for the dismantling of one train from the sorting hump, which consists of separate shunting operations and is determined by the formula [10]

$$
T_{d s}=T_{a r}+T_{c l}+T_{t h r}+T_{d i s}+T_{u p s}, \text { min. }
$$

where $T_{a r}$ - time of arrival of shunting locomotive to the fleet of arrival to the train, min;

$T_{c l}$ is the time of removal of means of fastening and coupling of locomotive, min;

$T_{t h r}$ is time of thrust of train to the sorting hump of hill, min;

$T_{\text {dis }}$ is time of dismantling the train from the sorting hump, min;

$T_{\text {ups }}$ si time for upsetting wagons on sorting tracks, min.

The technological time of arrival of a shunting locomotive to the reception park behind the train is determined by the formula

$$
T_{\mathrm{ar}}=\sum_{\mathrm{i}=1}^{\mathrm{n}} t_{\mathrm{h} / \mathrm{f}}+\sum_{\mathrm{j}=1}^{\mathrm{k}} t_{\mathrm{dm}}, \min
$$

where $t_{\mathrm{h} / \mathrm{f}}$ is duration of $i$-th half-flight of check-in operation, min;

$t_{d m}$ is time for changing the direction of movement of a shunting locomotive, the values are taken for shunting locomotives $-t_{d m}=0.15 \mathrm{~min}$.

The $t_{h / f}$ values are determined by the formula

$$
t_{\mathrm{h} / \mathrm{f}}=\left(\alpha_{\mathrm{ab}}+\beta_{\mathrm{ab}} m\right) \frac{v}{2}+0,06 \frac{l_{\mathrm{h} / \mathrm{f}}}{v}, \min .
$$

where $\alpha_{\mathrm{ab}}$ is coefficient that takes into account the time required to change the speed of locomotive by $1 \mathrm{~km} / \mathrm{h}$ during acceleration and the time required to change the speed of locomotive by $1 \mathrm{~km} / \mathrm{h}$ when braking, $\alpha_{\mathrm{ab}}=0.0407 \mathrm{~min} /(\mathrm{km} / \mathrm{h})$;

$\beta_{\mathrm{ab}}$ is coefficient taking into account additional changes in travel speed per one car in a shunting train by $1 \mathrm{~km} / \mathrm{h}$ during acceleration and additional changes in speed per car in a shunting train by $1 \mathrm{~km} / \mathrm{h}$ when braking, $\beta_{\mathrm{ab}}=0.0017 \mathrm{~min} /(\mathrm{km} / \mathrm{h}) ; \boldsymbol{m}$ is the number of wagons in the shunting train, $m=57$ wagons; $v$ is permissible speed during maneuvers (according to [11] $v=15 \mathrm{~km} / \mathrm{h}$ ); $l_{\mathrm{h} / \mathrm{f}}$ is half-flight length, $\mathrm{m}$.

The arrival of a shunting locomotive into the receiving fleet behind the train consists of two half-flights (with the sequential location of receiving and sorting fleet): 1. Following 
the locomotive from the sorting hump (hill) of hill to the end of reception park after the traffic light $M\left(l_{\mathrm{h} / \mathrm{f}}=1250 \mathrm{~m}\right) .2$. From traffic light $M$ to the appropriate track of reception park for the train $\left(l_{\mathrm{h} / \mathrm{f}}=350 \mathrm{~m}\right)$. Therefore, $n=2$ and $k=1$. Then, on the first half-flight $\mathrm{t}_{\mathrm{p} / \mathrm{p}}$ $=6.03 \mathrm{~min}$, and on the second $-\mathrm{t}_{\mathrm{h} / \mathrm{f}}=2.43 \mathrm{~min}$. Hence, according to the formula (2), according to the first option, $\mathrm{T}_{\operatorname{ar}(1)}=17.22 \mathrm{~min}$, and according to the second, $8.61 \mathrm{~min}$.

The time for removing the means of securing and coupling the locomotive $T_{c l}$ according to [12] is taken equal to 4.5 minutes for both options.

The technological time of advancing the train onto the sorting hump is determined by the formula

$$
T_{t h r}=\frac{0.06 \cdot L_{t h r}}{V_{t h r}}, \min .
$$

where $l_{t h r}$ is thrust half-flight length, $1_{\text {thr }}=230 \mathrm{~m} ; V_{t h r}$ is thrust speed.

The speed of advancing and breaking up depends on the average number of wagons in one uncoupling.

The average number of wagons in one uncoupling is determined by the following formula:

$$
m_{u n c}=m / g_{0}
$$

where $g_{0}$ is the number of uncouplings is determined according to [12] and $g_{0}=22$.

$$
m_{\text {unc }}=\frac{57}{22}=2.6 \text { wagons. }
$$

According to [12], knowing wagons, the speed of thrusting and dismantling $v_{d i s}=v_{t h r}=4,3 \mathrm{~km} / \mathrm{h}$ is determined. Then the technological time of thrust composition for both options

$$
t_{t h r}=\frac{0.06 \cdot 230}{4.3}=3.21 \mathrm{~min} .
$$

Technological time for breaking up the train from the sorting hump

$$
T_{\text {dis }}=t_{d i s}+\Delta t_{d i s}, \min
$$

where $t_{\text {dis }}$ is time to dismantling the train from the hill, excluding the additional time for maneuvers with wagons forbidden to dismount from the hill without a locomotive, min.;

$\Delta t_{\text {dis }}$ is the increase in the dissolution time for shuntings with forbidden downhill (FD) wagons, per one train to be dismantled, is taken to be equal to the dissolution time, min.

The time for dismantling trains from the hill, excluding additional time for FD wagons, is determined by the formula

$$
t_{d i s}=\frac{0.06 \cdot l_{w} \cdot m_{c}}{V_{d i s}}, \min .
$$


where $l_{w}$ is car length, $\mathrm{m} ; V_{\text {dis }}$ is dismantling speed; $m_{c}$ is average number of wagons in the dismantled train.

$$
t_{\text {dis }}=\frac{0.06 \cdot 14.5 \cdot 57}{4.2}=11.53 \mathrm{~min} .
$$

Then the dissolution time taking into account the FD will be equal to:

$$
T_{\text {dis }}=11.53+11.53=23.06 \mathrm{~min}
$$

Technological time for upsetting wagons from the side of the hill to eliminate "opening space" between groups of wagons on the tracks of the sorting yard is determined by the formula

$$
\begin{aligned}
& T_{u p s}=0.06 \cdot m, \min . \\
& \qquad T_{u p s}=0.06 \cdot 57=3.42 \mathrm{~min} .
\end{aligned}
$$

According to the first option, two TEM2 locomotives in the sorting yard operate separately during the upsetting operations. Therefore, for the first option, $t_{u p s}=1,71 \mathrm{~min}$.

Thus, according to the formula (1), the technological cycle of time for the disbandment of one train from the sorting hump is equal to:

- for the first option

$$
T_{\operatorname{dis}(I)}=17.22+4.5+3.21+11.53+1.71=38 \mathrm{~min},
$$

- for the second option

$$
T_{\text {dis }(I)}=8.61+4.5+3.21+11.53+1.71=31 \mathrm{~min},
$$

Hence, the duration of sorting hump cycle $T_{h c}$ (the period between two settlements through three trains) and the sorting hump technological interval $t_{h t i}$ are equal:

- for the first option

$$
\begin{gathered}
T_{h c(I)}=3 \cdot(17.22+4.5+3.21+11.53)+1.71=111 \mathrm{~min} . \\
t_{h t i(I)}=\frac{111}{3}=37 \mathrm{~min} .
\end{gathered}
$$

- for the second option

$$
\begin{gathered}
T_{h c(I)}=3 \cdot(8.61+4.5+3.21+11.53)+3.42=87 \mathrm{~min} . \\
t_{h t i(I I)}=\frac{87}{3}=29 \mathrm{~min} \mathrm{~min} .
\end{gathered}
$$

The maximum processing capacity of the slide is the most important indicator and is determined by the formula [13]: 


$$
B_{h}^{\max }=\frac{a_{\text {int }} \cdot\left(1440-\sum T_{p e r}\right)}{t_{h t i} \cdot \mu_{r e-s o r t} \cdot\left(1+p_{r}\right)} \cdot m, \text { wagons. }
$$

A coefficient takes into account possible interruptions in the operation of slide due to hostile routes. When transit parks are located parallel to the departure park for one-way stations, $\alpha_{\text {int }}=0.95$;

$\sum T_{\text {per-c }}-$ is the time of slide during the day by performing constant operations, 180 minutes;

$\mu_{\text {re-sort }}-$ is coefficient taking into account the re-sorting of a certain part of wagons due to the lack of number and length of sorting tracks during the periods of condensed arrival of trains, according to [13] $\mu_{r e-s o r t}=1.03$;

$\rho_{\text {non-dis }}-$ is coefficient taking into account failures of technical means and nondisengagement of wagons, according to [13] $\rho_{\text {non-dis }}=0,03$.

Thus, according to the formula (9), the maximum processing capacity of slide is equal to:

- for the first option

$$
B_{h(I)}^{\max }=\frac{0.95 \cdot(1440-180)}{37 \cdot 0.3 \cdot(1+0.03)} \cdot 57=1738 \text { wagons }
$$

- for the second option

$$
B_{h(I)}^{\max }=\frac{0.95 \cdot(1440-180)}{29 \cdot 0.3 \cdot(1+0.03)} \cdot 57=2217 \text { wagons. }
$$

The required processing capacity of slide depends on the number of processed trains $\left(N_{p r t r}\right)$ and is determined by the formula [13]:

$$
B_{h}^{c a p}=k_{\text {unev }} \cdot N_{p r t r} \cdot m, \text { wagons. }
$$

where $k_{\text {unev }}$ is the coefficient of annual unevenness of wagon-flows.

Currently, the number of processed trains at station " $\mathrm{X}$ " will be 26 , for such several train-flows $k_{\text {unev }}=1,15$. Then

$$
B_{h}^{c a p}=1.15 \cdot 26 \cdot 57=1704 \text { wagons. }
$$

The calculation results show that the consuming processing capacity of station " $\mathrm{X}$ " with the intensive wagon-flows is approaching the maximum. Those, any technical failure of sorting devices, require measures to increase the processing capacity of the station. When a more powerful TEM-7 hump locomotive is used, the maximum processing capacity of the slide increases by $27 \%$. 


\subsection{Method for substantiating the scope of efficiency of a shunting locomotive of TEM-7 series}

The capital expenditures for the purchase and implementation of the TEM-7 locomotive can be determined by enlarged meters. The cost of TEM-7 locomotive at the Central Bank rate as of 21.02.2021 is estimated at 4.61 billion soums [14]. To conduct an economic assessment, it is necessary to determine the operating costs of using the locomotive. Depreciation deductions are calculated using the formula:

$$
E_{\text {depr }}=\frac{C F A \cdot a_{\text {depr }}}{100}, \text { sum }
$$

where CFA is the cost of fixed assets; $a_{\text {depr }}$ is depreciation rate, $\%$.

For operating fixed assets, the full replacement cost is taken, for commissioned objects the initial one

$$
a_{\text {depr }}=\frac{100 \%}{T_{\text {use }}}
$$

where $T_{\text {use }}$ is useful life, 20 years.

$$
a_{\text {depr }}=\frac{100}{20}=5,0 \%
$$

Maintenance costs are calculated using the formula:

$$
E_{m . c . c}=\sum A C F \cdot k_{\text {cpre }}, \text { sum }
$$

where $\sum A C F_{\text {depr }}$ - amortized cost of fixed assets;

$\kappa_{\text {cpre }}$ is coefficient taking into account the costs of current repairs (taken 0.34)

$$
\begin{gathered}
E_{\text {depr }}^{T E M-7}=\frac{4.61 \cdot 5.0}{100}=230.588, \text { mln. sum } \\
E_{\text {m.c.c. }}^{T E M-7}=4.61 \cdot 0.34=1.568, \text { bil. Sum }
\end{gathered}
$$

The total annual expenses for the maintenance of the TEM-7 locomotive will be:

$$
E_{\text {TEM-7 }}=230.588+1567.998=1.799 \text {, bil. Sum }
$$

To assess the quality of proposed event, it is necessary to take into account the costs of maintaining two TEM-2 locomotives. The cost of TEM-2 locomotives, taking into account their service life, is 2.03 billion soums [15].

Depreciation costs for two TEM-2 locomotives will be:

$$
E_{a m}^{T E M-2}=\frac{(2.03+2.03) \cdot 5.0}{100}=203.460, \mathrm{mln} . \mathrm{Sum}
$$

Expenses for maintenance and replacement of equipment for two TEM-2 locomotives: 


$$
E_{\text {am }}^{T E M-2}=4.06 \cdot 0.34=1.384, \text { bil. Sum }
$$

The total annual expenses for the maintenance of TEM-2 locomotives will be:

$$
E_{\text {TEM-2 }}=230.460+1383.528=1.587 \text {, bil. Sum }
$$

The transition to the second option leads to savings on the wages of driver and driver's assistant, as well as on diesel fuel. The TEM-7 shunting locomotive consumes more fuel than the TEM-2. Therefore, the savings from fuel savings are not taken into account and the savings from the wages of driver and the assistant driver for the year $E_{w t}$ is calculated by the formula:

$$
E_{w t}=365 \cdot E_{w}, \text { sum }
$$

where $E_{w}$ are saving on wages of driver and driver's assistant per day, sum;

Saving on the wages of driver and assistant driver we take 19576817 sums per month [16], in $19576817 / 30=652561$ sums per day.

$$
E_{w t}=365 \cdot 652561=238.185, \text { mln. Sum }
$$

The total total annual expenses for the maintenance of TEM-2 locomotives with drivers and driver assistants will be:

$$
E_{T E M-2}^{\text {tot }}=1586.988+238.185=1.825 \text {, bil. Sum }
$$

Then the total additional costs for the maintenance of fleet of shunting locomotives will be:

$$
\Delta E=1798.586-1825.183=-26.597, \text { mln. Sum }
$$

The change in the technology of sorting stations implies an improvement in the performance of station according to the second option. Given the unit expense rates, the total savings can be determined. Before the introduction of new technology, the value of indicators is assumed to be equal to the value of plant standards. These include the total operating time of shunting $\left(\sum M h_{o t}=48 h /\right.$ day $)$. After the change in the station operation technology due to the introduction of TEM-7 locomotive and the reduction in the number of TEM-2 shunting locomotives, the considered indicators changed and amounted to the total operating time of shunting locomotives ( $\sum M h_{o t}=24 h /$ day $)$.

The total cost of maintaining a shunting locomotive per day can be defined as the sum of costs associated with the operation and downtime of locomotive,

$$
E_{\text {shun }}=\left(\sum M h_{o t}\right) \cdot e_{\text {shun }}^{\text {loc }}, \text { sum }
$$

where $\sum M h_{o t}$ are locomotive-hours of operation of shunting locomotive per day;

$e_{\text {shun }}^{\text {loc }}$ is cost of 1 locomotive-hour of work (accepted 218913 sum), sum.

Costs associated with the operation of locomotive by options: 


$$
\begin{gathered}
E_{\text {shun }}^{1 \text { opt }}=48 \cdot 218913=10,508, \text { mln } . \text { sum } \\
E_{\text {shun }}^{2 \text { opt }}=24 \cdot 218913=5,254, \text { mln } . \text { Sum }
\end{gathered}
$$

The total savings, taking into account the difference in the costs of maintaining and repairing the locomotive, will be:

$$
\begin{aligned}
& \Delta E_{\text {shun }}^{y}=\left(E_{\text {shun }}^{1 \text { opt }}-E_{\text {shun }}^{2 \text { opt }}\right) \cdot 365 \pm \Delta E, \text { sum } \\
& \Delta E_{\text {shun }}=(10,508-5,254) \cdot 365+26,597=1,918 \text {, bil. sum }
\end{aligned}
$$

After calculations, it can be concluded that the organization of station based on the use of TEM-7 locomotive can provide monetary savings, taking into account deductions for depreciation and maintenance in the amount of 1.918 billion sums in a year.

The calculation of the payback period for the introduction of TEM-7 locomotive at the sorting stations is as follows: the net present value by years (NPV) is calculated, and the first positive value of NPV will correspond to the payback period, in terms of resulting savings. Net Present Value can be calculated using the following formula [17]:

$$
N P V=\sum\left(R_{t}-C_{t}\right) \cdot \frac{1}{(1+E)}, \text { sum }
$$

where $C_{r c}$ are reconstruction costs (capital costs), sums; $R_{t}$ is total annual savings from the introduction of a new locomotive into operation, sums; $E$ is the discount rate; we take $0.12 ; t$ are years.

The calculation results are summarized in Table 1.

Table 1. Calculation of Net Present Value

\begin{tabular}{|l|l|l|l|l|l|}
\hline $\begin{array}{l}\text { Years, } \\
t\end{array}$ & $\begin{array}{l}\text { Reconstruction } \\
\text { costs (capital } \\
\text { costs), } \\
\text { billion sum. } \quad C_{r c},\end{array}$ & $\begin{array}{l}\text { Total annual } \\
\text { savings, } R_{t}, \\
\text { billion sum. }\end{array}$ & $\frac{1}{(1+\mathrm{E})}$ & $\begin{array}{l}\text { Annual } \\
\text { effect }\end{array}$ & $\begin{array}{l}\text { Net Present } \\
\text { Value } \\
\text { (NVP) }\end{array}$ \\
\hline 1 & 4.612 & 1.918 & 0.893 & -2.900 & -2.900 \\
\hline 2 & - & 1.918 & 0.797 & 1.529 & -1.370 \\
\hline 3 & - & 1.918 & 0.712 & 1.365 & -0.005 \\
\hline 4 & - & 1.918 & 0.636 & 1.219 & 1.214 \\
\hline
\end{tabular}

At costs in the initial year. the calculation is made according to the formula:

$$
N P V=\frac{\sum R_{t}}{(1+E)^{t}}-C_{t}
$$

For the 4th year of project

$N P V=1.214$ billion sum.

The exact value of payback period of capital investments is calculated using the following formula. years:

$$
T_{p p}=\frac{\left|N N P V_{t_{1}}\right| \cdot\left(t_{2}-t_{1}\right)}{P N P V_{t_{2}}+\left|N N P V_{t_{1}}\right|} .
$$

where $t_{1}$ is last year in which the NPV balance is negative (NNPV $\left.t_{1}\right)$ :

$t_{2}$ is the year in which the NPV balance became positive (PNPV $t_{2}$ ). 


$$
T_{p p}=3+\frac{0,005 \cdot(4-3)}{0,005+1,214}=3,004 \text { years }
$$

\section{Results and Discussion}

The results of calculations to substantiate the scope of application of shunting diesel locomotives at the sorting stations showed that today the required processing capacity of hill at station " $\mathrm{X}$ " is 1704 wagons and the maximum processing capacity of hill is 1738 wagons. When using the TEM-7 diesel locomotive. the maximum processing capacity of the hill increases by $27 \%$ and will amount to 2217 wagons. According to [18], the annual growth in the traffic volume is $8 \%$. Consequently, after a year, the technology of disbandment with two shunting locomotives will not master the volume of processed wagon-flow. The introduction of a more powerful locomotive of the TEM-7 series helps to preserve the processing capacity of the roller coaster for another 3 years. When two shunting locomotives TEM-2 are replaced by one TEM-7 at the "X" sorting stations due to investments in the purchase of a new TEM-7 locomotive, the payback period of the project will be 3 years and 1 month. This shows the feasibility of introducing a shunting locomotive TEM-7 at station "X".

\section{Conclusions}

To date, most of the shunting locomotives of the fleet have exhausted their standard service life. The technical condition of locomotives, which has exhausted this period, in most cases allows them to remain in operation, provided that the serviceability of vehicles is maintained by appropriate types of repair. The desire to reduce costs and improve operational efficiency determines the need for railways in rational traction facilities for shunting wagon sorting. Based on the foregoing, a variant of efficiency of replacing the TEM-2 shunting locomotive with TEM-7 is considered. The savings from replacing the existing two shunting locomotives of TEM-2 series with a locomotive of TEM-7 series will amount to 1.918 sums per year. The payback period will be 3 years and 1 month. The presented method of choosing the type of rolling stock for servicing the sorting hump operation of station makes it possible to determine an economically feasible option for organizing shunting operations. taking into account the characteristics of possible types of rolling stock.

\section{References}

1. Shavzis S.S. Avtomatizatsiya rascheta poezdoobrazovaniya na sortirovochnix stansiyax, p 157. (2003).

2. Butunov D.B.. Xudayberganov S.K. Suyunbayev Sh.M. Modeling of unproductive losses in the operation of a sorting station, Solid State Technology Blind Peer Revlew Referred Journal - USA. (63). - (6). pp. 6-19 (2020).

3. Aripov. N.. Aliyev. R.. Baratov. D.. Ametova. E. Features of Construction of Systems of Railway Automatics and Telemechanics at the Organization of High-Speed Traffic in the Republic of Uzbekistan. Procedia Engineering. 134. pp 175-180 (2016).

4. Suyunbaev Sh. M. Operativnoe planirovanie ekspluatatsionnoy raboti v usloviyax organizatsii dvijeniya gruzovix poezdov po tverdomu grafiku, Izvestiya Peterburgskogo universiteta putey soobsheniya, (3). pp. 15-24 (https://cyberleninka.ru/article/n/operativnoe-planirovanie-ekspluatatsionnoy-raboty- 
v-usloviyah-organizatsii-dvizheniya-gruzovyh-poezdov-po-tverdomu-grafiku (2010)

5. Kuznetsov V.. Lyubarskyi B.. Kardas-Cinal E.. Yeritsyan B.. Riabov I.. Rubanik I. Recommendations for the selection of parameters for shunting locomotives, Archives of Transport. 56. (4), pp. 119-133 (2020).

6. Hardi Hoimoja. Tanel Jalakas. Argo Rosin. Anton Rassylkin. Modernisation Issues of Diesel-Electric Shunting Locomotive Power Units, Scientific Journal of Riga Technical University Power and Electrical Engineering 27 (1). pp 57-62. DOI: 10.2478/v10144-010-0021-3 (2020)

7. Bobrovskiy V. I.. Kudryashov A. V. Optimizatsiya rejimov rasformirovaniya sostavov na sortirovochnix gorkax, Nauka i progress transporta. Vestnik Dnepropetrovskogo natsionalnogo universiteta jeleznodorojnogo transporta. 32. pp 224-229, (2010).

8. Demchenko E.B. Otsenka rasxoda topliva manevrovimi teplovozami pri rasformirovanii sostavov na sortirovochnix gorkax, Transportnie sistemi i texnologii perevozok. (6). pp 39-46 (2013).

9. Korjenevich I. P. Otsenka rasxoda topliva ili elektroenergii cherez mexanicheskuyu rabotu lokomotiva, Nauka i progress transporta. Vestnik Dnepropetrovskogo natsionalnogo universiteta jeleznodorojnogo transporta. (29). pp 88-90 (2009).

10. Normi vremeni na manevrovie raboti. vipolnyaemie na jeleznodorojnix stansiyax OAO «RJD». normativi chislennosti brigad manevrovix lokomotivov. M.: OAO «RJD».p 102, (2006).

11. Pravila texnicheskoy ekspluatatsii jeleznix dorog Respubliki Uzbekistan (s izmeneniyami i dopolneniyami na 02.10.2012 goda). - T.: GI "Uzgosjeldornadzor". p 204. (https://lex.uz/acts/1801692 ). (2013).

12. Metodicheskie ukazaniya po raschetu norm vremeni na manevrovie raboti. vipolnyaemie na jeleznodorojnom transporte. MPS RF. M. p 84, (1998).

13. Proektirovanie sortirovochnix gorok bolshoy i sredney moshnosti. Uchebnoe posobie. Yu.I. Efimenko. V.S. Suxodoev. V.I. Smirnov. L.A. Oleynikova. V.V. Vasilev. SPb: PGUPS. p 63. (2008).

14. Pestretsov E.A. TEM-7A 34000000 rub. (https://velikiynovgorod.flagma.ru/tem-7ao3735492.html ).

15. Beliy S.E. OOO «Remjeldortex» prodaet sobstvenniy manevroviy teplovoz TEM2U (https://yaroslavl.promportal.su/goods/1254441/teplovoz-tem-2u.htm ).

16. Rasulov M.X. Organizatsiya jeleznodorojnix perevozok: teoriya $i$ praktika: monografiya. Tashkent: «Ilm-ziyo-zakovat».p 400. (2019)

17. Ekonomika jeleznodorojnogo transporta, ucheb. dlya vuzov j.-d. transporta, Pod red. Tereshinoy N.P.. Lapidusa B.M.. Trixunkova M.F. - M.: UMS JDT. 2008. - 996 s. (http://www.labrate.ru/education/tereshina_economics_of_rail_transport-2006.pdf ). (2006).

18. Rasulov M.X.. Suyunbaev Sh.M.. Masharipov M.N. Problemi povisheniya effektivnosti ekspluatatsii lokomotivov, Nauchnie trudi respublikanskoy nauchnotexnicheskoy konferensii s uchastiem zarubejnix uchenix "Resursosberegayushie texnologii na jeleznodorojnom transporte" (18-19 dekabrya 2018 g.), Pod red. prof. A.I. Adilxodjaev. - T.: TashIIT. 2019. - S. 8-10.(2018). 